\title{
The Current Status of Alternative Methods for Cosmetics Safety Assessment in China
}

\author{
Fei-ya Luo, Zhe Su, Jing Wu, Feng-lan Zhang, Shu-xia Xing, Gang-li Wang and Yong Lu \\ National Institutes for Food and Drug Control, Beijing, China
}

Safety assessment is important to ensure the quality and safety of cosmetics. Owing to the progress of technology and the $3 \mathrm{R}$ principle, validated alternative approaches can meet the needs of local toxicity evaluations for cosmetics. China is actively promoting research, validation/verification work, and regulatory acceptance of alternative methods in cosmetics safety assessment. The NIFDC (National Institutes for Food and Drug Control), as the scientific subordinate body of China NMPA (National Medical Products Administration), is assigned to conduct cosmetics alternative validation/verification and research projects. After validation/verification, public opinion on an alternative method is solicited and then the method is submitted to the Experts Committee of Cosmetics Standards by the Secretary of NIFDC. After approval by the committee, the method is adopted as one of the toxicological testing approaches in the Safety and Technical Standards for Cosmetics (STSC) and published by NMPA. This letter summarizes the status of alternative methods for cosmetics safety assessment worldwide, and provides commentary on relevant cosmetics legislation in China.

In 1959, British scientists first put forward the 3R (reduction, refinement, and replacement) principle of animal welfare and animal protection in scientific research (Russell and Burch, 1959). With the continuous progress of science and technology, cellular and molecular biology methods were introduced into modern toxicological research. New in vitro technologies such as reconstruction of tissues and organs, computational toxicology, and other predictive methods were developed to gradually replace animal experiments ${ }^{1}$. In recent years, the need for non-animal test methods has become greater, especially in cosmetics safety assessment. Besides scientific and animal welfare considerations, alternative methods are also of great importance from the perspective of regulatory requirements. With the implementation of a ban on animal testing for cosmetic ingredients and products in the European Union ${ }^{2}$ and other countries, the use of non-animal testing methods for cosmetic safety assessment has become a worldwide goal ${ }^{3}$. Alternative methods should bring together several important aspects including advantages in accuracy, sensitivity, cost, etc., and compliance with the 3Rs principle should be considered first and foremost.

Information on the acceptance status of alternative methods was collected from the websites of ICCVAM (Interagency Coordinating Committee on the Validation of Alternative Methods), EURL-ECVAM (European Union Reference Laboratory for alternatives to animal testing), JaCVAM (Japanese Center for the Validation of Alternative Methods), KoCVAM (Korean Center for the Validation of Alternative Methods), and OECD (Organisation for Economic Cooperation and Development) test guidelines, and the alternative methods that are already accepted and that will be adapted to the STSC in China are listed in Table 1. Currently, five alternative methods are included in China's cosmetics standards and four methods have completed verification and are open for public opinion on the NIFDC website. Together they cover skin irritation/corrosion, ocular toxicity, skin sensitization, phototoxicity, and genotoxicity, i.e., the basic and most important toxicological endpoints of cosmetics safety assessment ${ }^{4,5,6,7}$.

\section{Cosmetics regulatory framework in China}

In 1989, supervision and management of cosmetics entered China's legal system when the China State Council approved the "Regulations concerning the hygiene supervision over cosmetics" $"$. The function of cosmetics supervision was transferred

\footnotetext{
1 https://bit.ly/1t3y7WK

2 https://bit.ly/2QIQzKh

3 http://aei.pitt.edu/38396/1/COM_(2011)_558_final.pdf (accessed 24.02.2018).

4 http://samr.cfda.gov.cn/WS01/CL1870/166246.html (accessed 31.07.2018).

5 http://samr.cfda.gov.cn/WS01/CL0087/176283.html (accessed 31.07.2018).

6 http://www.nifdc.org.cn/CL0901/10648.html (accessed 28.02.2018).

7 http://www.nifdc.org.cn/CL0901/11184.html (accessed 02.07.2018).

8 http://samr.cfda.gov.cn/WS01/CL1166/110200.html
}

Received August 2, 2018; Accepted November 7, 2018; (C) The Authors, 2018.

ALTEX 36(1), 136-139. doi:10.14573/altex.1808021

Correspondence: Gang-li Wang, PhD, Tiantan Xili, No. 2 100050 Beijing, China (wanggl@nifdc.org.cn)
This is an Open Access article distributed under the terms of the Creative Commons Attribution 4.0 International license (http://creativecommons.org/licenses/by/4.0/) which permits unrestricted use, distribution and reproduction in any medium, provided the original work is appropriately cited. 
Tab. 1: The status of main alternative methods in cosmetics

\begin{tabular}{|c|c|c|c|c|c|c|c|}
\hline $\begin{array}{l}\text { Toxicology area/ } \\
\text { Endpoint }\end{array}$ & Methods & OECD & ICCVAM & ECVAM & JaCVAM & KoCVAM & STSC \\
\hline \multirow[t]{5}{*}{ Ocular toxicology } & $\begin{array}{l}\text { Bovine corneal opacity and permeability test } \\
\text { method for identifying i) chemicals inducing } \\
\text { serious eye damage and ii) chemicals } \\
\text { not requiring classification for eye irritation or } \\
\text { serious eye damage (BCOP) }\end{array}$ & $\begin{array}{l}\text { TG } 437 \\
2017\end{array}$ & $\checkmark$ & $\checkmark$ & $\checkmark$ & $\checkmark$ & \\
\hline & $\begin{array}{l}\text { Fluorescein leakage test method for } \\
\text { identifying ocular corrosives and severe } \\
\text { irritants (FL) }\end{array}$ & $\begin{array}{l}\text { TG } 460 \\
2017\end{array}$ & $\checkmark$ & $\checkmark$ & $\checkmark$ & & \\
\hline & $\begin{array}{l}\text { Short time exposure in vitro test method } \\
\text { for identifying i) chemicals inducing serious } \\
\text { eye damage and ii) chemicals not requiring } \\
\text { classification for eye irritation or serious } \\
\text { eye damage (STE) }\end{array}$ & $\begin{array}{l}\text { TG } 491 \\
2018\end{array}$ & $\checkmark$ & $\checkmark$ & $\checkmark$ & $\checkmark$ & $\begin{array}{l}\text { open for } \\
\text { opinions }\end{array}$ \\
\hline & $\begin{array}{l}\text { Reconstructed human cornea-like epithelium } \\
\text { (RhCE) test method for identifying chemicals } \\
\text { not requiring classification and labelling } \\
\text { for eye irritation or serious eye damage } \\
\text { (EpiOcular, SkinEthic, LabCyte CORNEA- } \\
\text { MODEL24 EIT) }\end{array}$ & $\begin{array}{l}\text { TG } 492 \\
2018\end{array}$ & $\checkmark$ & $\checkmark$ & $\checkmark$ & $\begin{array}{l}\boldsymbol{\sim} \\
\text { (MCTT } \\
\text { HCE in } \\
\text { progress) }\end{array}$ & \\
\hline & Collagen gel - eye irritation test (Vitrigel-EIT) & $\begin{array}{l}\text { work plan } \\
2017)\end{array}$ & $\checkmark$ & $\begin{array}{l}\text { ICATM } \\
\text { accepted } \\
\text { (JaCVAM) }\end{array}$ & Ongoing & & \\
\hline \multirow[t]{3}{*}{$\begin{array}{l}\text { Dermal corrosion/ } \\
\text { irritation }\end{array}$} & $\begin{array}{l}\text { In vitro skin corrosion: Transcutaneous } \\
\text { electrical resistance test method (TER) }\end{array}$ & $\begin{array}{l}\text { TG } 430 \\
2015\end{array}$ & $\checkmark$ & $\checkmark$ & $\boldsymbol{\nu}$ & & $\checkmark$ \\
\hline & $\begin{array}{l}\text { In vitro skin corrosion: Reconstructed human } \\
\text { epidermis (RHE) test method (Episkin, } \\
\text { EpiDerm, SkinEthic, epiCS) }\end{array}$ & $\begin{array}{l}\text { TG } 431 \\
2016\end{array}$ & $\checkmark$ & $\checkmark$ & $\begin{array}{l}\boldsymbol{V} \\
\text { (LabCyte } \\
\text { EPI will be } \\
\text { started) }\end{array}$ & & \\
\hline & $\begin{array}{l}\text { In vitro skin irritation: Reconstructed human } \\
\text { epidermis test method (Episkin, EpiDerm, } \\
\text { SkinEthic, LabCyte, EPI-MODEL24) }\end{array}$ & $\begin{array}{l}\text { TG } 439 \\
2015\end{array}$ & $\checkmark$ & $\checkmark$ & $\boldsymbol{\nu}$ & $\checkmark$ & \\
\hline \multirow[t]{7}{*}{ Skin sensitization } & $\begin{array}{l}\text { Skin sensitization: Local lymph node assay: } \\
\text { DA }\end{array}$ & $\begin{array}{l}\text { TG 442A } \\
2010\end{array}$ & $\boldsymbol{\nu}$ & $\checkmark$ & $\checkmark$ & $\checkmark$ & $\begin{array}{l}\text { open for } \\
\text { opinions }\end{array}$ \\
\hline & $\begin{array}{l}\text { Skin sensitization: Local lymph node assay: } \\
\text { BrdU-ELISA or -FCM }\end{array}$ & $\begin{array}{l}\text { TG 442B } \\
2018\end{array}$ & $\checkmark$ & $\boldsymbol{\nu}$ & $\checkmark$ & $\checkmark$ & $\begin{array}{l}\text { open for } \\
\text { opinions }\end{array}$ \\
\hline & $\begin{array}{l}\text { In chemico skin sensitization: Direct peptide } \\
\text { reactivity assay (DPRA) }\end{array}$ & $\begin{array}{l}\text { TG 442C } \\
2015\end{array}$ & $\checkmark$ & $\checkmark$ & $\checkmark$ & $\checkmark$ & $\begin{array}{l}\text { open for } \\
\text { opinions }\end{array}$ \\
\hline & $\begin{array}{l}\text { In vitro skin sensitization: ARE-Nrf2 luciferase } \\
\text { test method (KeratinoSens, Lu-Sens) }\end{array}$ & $\begin{array}{l}\text { TG 442D } \\
2018\end{array}$ & $\checkmark$ & $\checkmark$ & $\begin{array}{l} \\
\text { (Keratino } \\
\text { Sens) }\end{array}$ & $\begin{array}{l}\text { (Keratino } \\
\text { Sens) }\end{array}$ & \\
\hline & $\begin{array}{l}\text { In vitro skin sensitisation assays addressing } \\
\text { the key event on activation of dendritic cells } \\
\text { on the adverse outcome pathway for skin } \\
\text { sensitisation (h-CLAT+U-SENS+IL-8) }\end{array}$ & $\begin{array}{l}\text { TG 442E } \\
2018\end{array}$ & $\checkmark$ & $\checkmark$ & $\boldsymbol{v}$ & $\checkmark$ & \\
\hline & In vitro skin sensitisation: Sens-IS & $\begin{array}{l}\text { work plan } \\
(2016)\end{array}$ & & ongoing & & & \\
\hline & $\begin{array}{l}\text { In vitro skin sensitisation assay: Genomic } \\
\text { allergen rapid detection (GARDskin, } \\
\text { GARDprotency) }\end{array}$ & $\begin{array}{l}\text { work plan } \\
(2016)\end{array}$ & $\checkmark$ & ongoing & & & \\
\hline \multirow[t]{2}{*}{ Skin phototoxicity } & In vitro 3T3 NRU phototoxicity test & $\begin{array}{l}\text { TG } 432 \\
2004\end{array}$ & $\checkmark$ & $\checkmark$ & $\checkmark$ & $\checkmark$ & $\checkmark$ \\
\hline & Reactive oxygen species assay (ROS) & $\begin{array}{l}\text { work plan } \\
(2016)\end{array}$ & $\checkmark$ & $\begin{array}{l}\text { ICATM } \\
\text { accepted } \\
\text { (JaCVAM) }\end{array}$ & $\checkmark$ & & \\
\hline
\end{tabular}




\begin{tabular}{|c|c|c|c|c|c|c|c|}
\hline $\begin{array}{l}\text { Toxicology area/ } \\
\text { Endpoint }\end{array}$ & Methods & OECD & ICCVAM & ECVAM & JaCVAM & KoCVAM & STSC \\
\hline \multirow{7}{*}{$\begin{array}{l}\text { Genotoxicity/ } \\
\text { Carcinogenic, } \\
\text { Mutagenic } \\
\text { Reproduction }\end{array}$} & In vitro mammalian cell micronucleus test & $\begin{array}{l}\text { TG } 487 \\
2016\end{array}$ & $\checkmark$ & $\checkmark$ & $\checkmark$ & & \\
\hline & $\begin{array}{l}\text { In vitro mammalian chromosomal aberration } \\
\text { test }\end{array}$ & $\begin{array}{l}\text { TG } 473 \\
2016\end{array}$ & $\checkmark$ & $\checkmark$ & $\checkmark$ & & $\checkmark$ \\
\hline & $\begin{array}{l}\text { In vitro mammalian cell gene mutation tests } \\
\text { using the thymidine kinase assay }\end{array}$ & $\begin{array}{l}\text { TG } 490 \\
2016\end{array}$ & $\checkmark$ & $\checkmark$ & $\checkmark$ & & $\checkmark$ \\
\hline & $\begin{array}{l}\text { In vitro mammalian cell gene mutation tests } \\
\text { using the Hprt and xprt genes }\end{array}$ & $\begin{array}{l}\text { TG } 476 \\
2016\end{array}$ & $\checkmark$ & $\checkmark$ & $\checkmark$ & & $\checkmark$ \\
\hline & $\begin{array}{l}\text { In vitro micronucleus: Reconstructed human } \\
\text { epidermis }\end{array}$ & & & ongoing & open & & \\
\hline & $\begin{array}{l}\text { In vitro Syrian hamster embryonic cells (SHE) } \\
\text { cell transformation assays (CTAs) }\end{array}$ & $\begin{array}{l}\text { GD } 214 \\
2015\end{array}$ & & $\checkmark$ & $\checkmark$ & & \\
\hline & $\begin{array}{l}\text { In vitro Bhas } 42 \text { cell transformation assay } \\
\text { (CTA) }\end{array}$ & $\begin{array}{l}\text { GD } 231 \\
2016\end{array}$ & & $\checkmark$ & ongoing & & \\
\hline
\end{tabular}

$\checkmark$ : method has already been validated and/or accepted Information from CFDA ${ }^{\mathrm{a}}$, ICCVAM ${ }^{\mathrm{b}}, \mathrm{JRC}^{\mathrm{c}}, \mathrm{JaCVAM}^{\mathrm{d}}, \mathrm{KOCVAM}^{\mathrm{e}}, \mathrm{OECD}^{\mathrm{f}}$ websites, updated in July 2018

a http://samr.cfda.gov.cn/WS01/CL0087/140161.html (accessed 31.07.2018).

b https://ntp.niehs.nih.gov/pubhealth/evalatm/accept-methods/index.html (accessed 30.03.2018).

${ }^{c}$ https://bit.ly/2DrKZmP (accessed 15.03.2018).

d http://www.jacvam.jp/en_effort/index.html (accessed 29.01.2018).

e http://www.nifds.go.kr/kocvamen/ (accessed 10.05.2018).

f https://doi.org/10.1787/20745788

from the former Ministry of Health to the former State Food and Drug Administration (SFDA) in 2008, and after a series of institutional reforms (SFDA is known as CFDA since 2013), and development and revision of cosmetics regulations and standards, the NMPA has now taken charge of cosmetics supervision. The new "Cosmetics Supervision and Administration Regulation", revised by the former CFDA, was opened for public opinion in $2015^{9}$, and is entering the legislation plan now.

In 2010, safety assessment was officially introduced into cosmetics supervision in China when the former SFDA introduced safety assessment procedures in management of risky substances that may exist in $\operatorname{cosmetics}^{10}$. In 2013, the former CFDA released a proclamation to amend several matters concerning the registration and management of cosmetics ${ }^{11}$. According to this proclamation, "domestic non-special-use cosmetics whose risk can be fully confirmed by results of safety assessment can be exempted from relevant toxicological tests of products", greatly encouraging the use of safety risk assessment to ensure a products' safety and reduce toxicological tests for cosmetics. In 2015, the former CFDA drafted a "Guidance on Risk Assessment of Cosmetics Safety" (draft open for public opinion) in order to regulate and guide the implementation of cosmetics safety assessment ${ }^{12}$. In 2016, the former CFDA adopted the 3T3 NRU Phototoxicity Assay into the $\mathrm{STSC}^{4}$, which was a milestone marking the formal entry of animal alternative methods into China's cosmetics standards system.

\section{Challenges and problems of developing alternative methods}

With increasing numbers of mature in vitro assays being validated and accepted worldwide, the research and validation/verification of alternative methods has started to blossom in China. On the basis of respecting the 3 Rs principle, China aspires to promote the research and application of alternative methods in the field of cosmetics safety assessment. But we still face numerous challenges and problems in developing alternative methods.

The alternative methods accepted as OECD test guidelines are designed to test chemicals or mixtures of specific concentrations. According to the authors' estimate, one-third of the 8,783 ingredients included in the "Inventory of used cosmetic ingredients" 13 in China are extracts of animals or plants with uncertain composition and concentrations. These kinds of raw materials are

\footnotetext{
9 http://zqyj.chinalaw.gov.cn/readmore?listType=1\&id=147

10 http://samr.cfda.gov.cn/WS01/CL0846/52911.html (accessed 31.07.2018).

11 http://samr.cfda.gov.cn/WS01/CL0087/95194.html (accessed 31.07.2018).

12 http://samr.cfda.gov.cn/WS01/CL0781/134401.html (accessed 31.07.2018)

13 http://samr.cfda.gov.cn/WS01/CL1870/140365.html (accessed 31.07.2018).
} 
complex and final cosmetic products are often complex mixtures of dozens of such raw materials. The physical forms, characteristics, and colors of the finished products can all affect the test results. Owing to the testing requirements for final products in China and the specific characteristics of China's cosmetic raw ingredients, alternative methods need to be further developed and adapted before verification, and cannot simply be translated and adopted.

In addition, there are some problems regarding the import of specific cell lines, tissue models, and facilities required to perform alternative methods. For example, the reconstructed human skin and/or corneal models validated by OECD are currently only produced by overseas suppliers and may not retain their bioactivity after long-distance delivery to China. The facilities of BCOP (Bovine Corneal Opacity and Permeability Test Method) are currently supplied by a single entity in China at a prohibitively high price. Also, many of the cell lines used for in vitro / in chemico skin sensitization tests have not been officially introduced or imported into China yet (sometimes this is because China is not an OECD member country), and some sensitization tests have strong patent protection. All these factors slow down the promotion and acceptance of alternative tests, which may be contrary to the will of the assays' developers.

\section{Prospects of alternative methods}

The NMPA has organized research projects to verify alternative methods for ocular toxicity, skin irritation/corrosion, skin sensitization, phototoxicity and genotoxicity testing. The 3T3 NRU phototoxicity assay and TER (Transcutaneous Electrical Resistance Test Method) skin corrosion assay, both for cosmetics ingredients, already have been adopted to STSC. Chinese authorities will continue to carry out further research on relevant alternative methods suitable for the local cosmetics' characteristics and needs of the local cosmetics industry. The public proposals for revising STSC are published annually on the NIFDC website (always mid-year).
China has always held a positive stance on the 3 Rs principle and actively promotes the application of cosmetic safety risk assessment. Many stakeholders from registered test institutions, universities and academies, third-party test agencies, and industry have actively established alternative methods. Some laboratories, including NIFDC, have obtained test accreditation from CNAS (China National Accreditation Service for Conformity Assessment). Since there are no unified national standards for in vitro toxicity laboratory qualification and standardized documentation for the validation/verification of alternative methods, the CNAS accreditation might help to meet the increasing needs of alternative testing markets.

The cosmetics safety assessment is based on strong technical support and advanced industrial development. China's cosmetics industry is mainly SME (small and medium enterprise), whose technical and economical capability is relatively weak. In order to help promote and spread knowledge on and use of alternative methods and the 3Rs principle, NIFDC holds a hands-on training workshop annually together with IIVS (Institute for In Vitro Science, US) since 2013. International conferences and seminars relevant to alternative toxicology and safety assessment of cosmetics also have been held successfully several times in China.

Although there are many challenges, Chinese authorities have made strides towards improving and practicing the cosmetics safety assessment and alternative tests. Currently, NIFDC has established a special work group for research and verification/ validation of alternative methods for cosmetics testing, which has a similar function to a "CVAM" (Center for the Validation of A1ternative Methods), focused especially on cosmetics in China. It can help to bridge the scientific, regulatory, and commercial needs in the field of cosmetics safety assessment efficiently.

\section{Reference}

Russell, W. M. S. and Burch, R. L. (1959). The Principles of Humane Experimental Technique (913-924). Methuen. http:// altweb.jhsph.edu/pubs/books/humane_exp/het-toc

\section{LINZ 2019}

22nd European Congress on Alternatives to Animal Testing

EUSAAT 2019

19th Annual Congress of EUSAAT

EUSAAT

European Society for Alternatives to Animal Testing

The European 3Rs Society

www.eusaat-congress.eu

\section{5 - 28 August 2019 - University of Linz, Austria}

